\title{
Desain Pembelajaran Sastra Berbasis Kearifan Lokal (Cerita Rakyat Dan Konsep Maja Labo Dahu) Sebagai Upaya Penanaman Pendidikan Karakter
}

\author{
${ }^{1}$ Ria Hendriana, ${ }^{2}$ Herman \\ ${ }^{12}$ Universitas Qamarul Huda Badaruddin
}

\begin{abstract}
Abstrak. Pembelajaran sastra berbasis kearifan lokal (cerita rakyat dan konsep maja labo dahu) merupakan salah satu solusi untuk membangkitkan imajinasi peserta didik serta sebagai solusi dalam menanamkan penerus bangsa mengalami deklinasi moral. Itu terbukti dengan adanya pernikahan sedarah, anak memperkosa ibu kandungnya, korupsi semakin membudaya, tawuran antar pelajar semakin menjadi, perampokkan semakin subur, dan sejenis kejahatan lainnya. Maka, konsep kearifan loka (cerita rakyat dan konsep maja labo dahu) menjadi alat kontrol bagi setiap individu atau kelompok jika ingin bertindak, baik secara horisontal (hubungan sesama manusia), maupun secara vertikal (hubungan kepada Allah), harus dijadikan media pembelajaran di sekolah-sekolah khususnya di Bima. Penelitian ini bertujuan untuk, a) Mengetahui pembelajaran sastra berbasis kearifan lokal (cerita rakyat dan ungkapan maja labo dahu) dapat menanamkan nilai-nilai pendidikan karakter pada siswa, b) mengetahui desain pembelajaran sastra berbasis kearifan lokal (cerita rakyat dan konsep maja labo dahu) dalam sebagai upaya menanamkan nilai-nilai pendidikan karaker pada siswa, dan c) untuk mengetahui relevansi pembelajaran sastra berbasis kearifan lokal (cerita rakyan dan konsep maja labo dahu) dengan penanaman nilai-nilai pendidikan karakter siswa. Penelitian ini menggunakan design penelitian pengembangan. Penelitian ini dilakukan dengan cara : (a) studi literatur dan studi lapangan (penelitian) yang hasilnya akan dijadikan dasar bagi perencanaan dalam mengembangkan model pembelajaran, (b) pengembangan model melalui uji coba terbatas dan hasil penyempurnaan model pembelajaran, dan (c) uji validasi model untuk mengidentifikasi keunggulan model hasil pengembagan. Sedangkan tehknik pengumpulan data dalam penelitian ini adalah (a) melalui tes, (b) melalui observasi, (c) Wawancara, dan (d) Analisis dokumen. Adapun langkah analisis data dalam penelitian ini adalah (a) pengumpulan data, (b) reduksi data, (c) penyajian data, dan (d) penarikan simpulan. Adapun hasil penelitian dalam penelitian ini menunjukan bahwa kearifan lokal dalam hal ini ungkapan maja labo dahu memiliki kesamaan dengan pendidikan karakter. Dalam kalimat lain bahwa nilai - nilai ungkapan maja labo dahu dapat dijadikan bahan pembejaran pada mata pelajaran bahasa dan sastra di SMP sederajat, dan desain pembejalaran berbasis kearian lokal merupakan salah satu metode yang harus dipilih oleh guru guru dalam mendesain bahan ajar guna menanamkan nilai -nilai pendidikan karakter pada peserta didik, khususnya pada peserta didik di tingkat Sekolah Menengah Pertama (SMP).
\end{abstract}

Kata Kunci : Cerita Rakyat, Pendidikan Karakter, Antropologi Sastra

\section{PENDAHULUAN}

Belajar merupakan proses interaksi antar guru dan murid, antar dosen dan mahasiswa. Belajar dapat juga diartikan sebagai proses transfer ilmu (kwonlegde) atau tukar pengalaman baik dilakukan oleh guru dan murid, antara dosen dan mahasiswa, maupun bagi siapapun yang melakukan transfer ilmu (tranfer knowlegde) atau tukar pengalaman tersebut yang bersifat edukatif dalam rangka mereubah tingkah laku individu. Dalam proses belajar, dibutuhkan media pembelajaran untuk mendukung keberhasilan atau tujuan pembelajaran tersebut. Salah satunya adalah media pembelajaran tersebut adalah bahan ajar. Sejalan dengan itu, Jasmadi dalam Istiqomah, (2018 : 143), bahwa bahan ajar adalah "Seperangkat sarana atau alat pembelajaran yang berisikan materi, pembelajaran, metode, batasan-batasan dan cara mengevaluasi yang didesain secara sistematis dan menarik dalam rangka mencapai tujuan pembelajaran."

Merujuk dari pedapat di atas, bahwa bahan ajar merupakan salah satu alat untuk menyukseskan tujuan pembelajaran. Dalam hal ini, peneliti akan mencoba mengunakan bahan ajar "cerita rakyat lokal" dalam pembelajaran sastra sebagai upaya penanaman nilai-nilai pendidikan karakter pada siswa Sekolah Menengah Pertama (SMP) atau Madrasah. Pembelajaran sastra mestinya mendapat perhatian khusus baik itu di lingkungan masyarakat maupun pada pemerintah (melalui pendidikan formal dan non formal). Selama ini, pembejalaran sastra jarang dan bahkan tidak pernah mendapatkan tempat yang baik pada pemerintah melalui lembaga pendidikan tersebut. Ada banyak faktor yang menyebabkan pembelajaran sastra dilupakan, yakni pertama, guru kebanyakan tidak memiliki kompetensi 
dalam memahami sastra, dan kedua meleburnya sastra dalam pembelajaran bahasa baik itu bahasa Indonesia maupun bahasa asing (Inggris dan Arab). Dalam kalimat lain bahwa pembelajaran sastra dijadikan bahan ajar sampingan oleh guru-guru di sekolah-sekolah.

Sejalan dengan itu, Ismail dalam Sumayana, (2017 : 22), mengatakan bahwa selama enam dekade terakhir ini sejak 1945 hingga dekade pertama tahun 2000 pembelajaran sastra kurang membawa pencerahan bagi siswa. Ironisnya, di tengah derap kemajuan dunia pendidikan yang demikian pesat hingga kini belum juga ditemukan format pembelajaran sastra yang mencerahkan sebagai solusi guna mengatasi kondisi suram tersebut. Padahal pembelajaran sastra merupakan salah satu solusi untuk membangkitkan kreatifitas peserta didik dan juga sebagai solusi dalam menanamkan nilainilai pendidikan karakter pada peserta didik. Sebab dalam karya sastra (cerita rakyat) memiliki sisi kemanusiaan yang dapat menambah wawasan dan pengetahuan bagi peserta didik. Untuk itu, pembelajaran sastra di anggap peting untuk membentuk karakter dan watak peserta didik. Menurut Tindaon, (2017 : 2) bahwa pembelajaran sastra harus diarahkan pada dua tuntutan, yakni pertama, pembelajaran sastra hendaknya mampu membina perasaan yang lebih tajam. Seseorang yang telah banyak mendalami berbagai karya sastra biasanya memiliki perasaan yang lebih peka untuk menunjuk hal mana yang bernilai dan mana yang tak bernilai. Tuntutan kedua, bahwa pembelajaran sastra hendaknya dapat memberikan bantuan dalam usaha mengembagkan berbagai kualitas kepribadian siswa yang antara lain meliputi ketekunan, kepandaian, pengimajian, dan penciptaan.

Di setiap daerah, tentnunya memiliki sebuah aturan atau tata nilai sosial yang mengikat suatu masyarakatnya. Begitu juga daerah Bima. Daerah Bima merupakan bagian dari Nusantara, tentu memiliki tata aturan atau norma sosial yang mengikat suatu masyarakatnya, norma sosial itu teringklud di dalam sebuah konsep besar, yakni konsep maja labo dahu. Konsep maja labo dahu merupakan falsafah masyarakat Bima yang memiliki nilai yang tak terhingga. Konsep maja labo dahu memiliki makna kurang lebih malu dan takut jika melalukan hal - hal yang melenceng dari ajaran agama yang mereka anut, yakni agama Islama, termasuk korupsi, perampok tawuran antar pelajar, dan sederet kejahatan lainnya. Konsep maja labo dahu, jika ditarik ke dalam pendidikan karakter, dan mengingat kondisi Bima sekarang ini semakin tidak "memiliki arah,"(korupsi semakin membudaya, tawuran antar pelajar semakin menjadi, perampokkan semakin subur, dan sejenis kejahatan lainnya) maka konsep maja labo dahu menjadi alat kontrol bagi setiap individu atau kelompok jika ingin bertindak, baik secara horisontal (hubungan sesama manusia), maupun secara vertikal (hubungan kepada Allah).

Melihat gejala yangg muncul di Bima akhir - akhir ini, maka peneliti mencoba menawarkan solusi terkait pengajaran sastra dengan menggunakan pembelajaran sastra berbasis kearifan lokal, yakni Desain Pembelajaran Sastra Berbasis Kearifan Loka (Cerita Rakyat dan Maja Labo Dahu) sebagai upaya penanaman pendidikan karakter pada peserta didik. Pembelajaran sastra berbasis kearifan lokal (menggunakan cerita rakyat dan konsep maja labo dahu) merupakan langkah antisipatif untuk meminimalisir dekinasi moral yang melanda generasi penerus bangsa saat ini. Ide ini dilakukan atas dasar bahwa pertama : penelitian terkait pengajaran sastra berbasis kearifan lokal sangat jarang dilakukan, padahal pengajaran sastra berbasis kearifan lokal sangat berguna untuk meminimalisir kejahata kejahatan yang dilakukan oleh generasi penerus bangsa. Sebab pengajaran sastra berbasis kearifan lokal merupakan pengajaran sastra yang memasukan nilai - nilai kearifan lokal atau nilai - nilai budaya loka yang ada di daerah tersebut, salah satu contoh konsep maja labo dahu dan cerita rakyat yang ada di daerah tersebut, kedua : pendidikan karakter sangat dibutuhkan oleh generasi penerus bangsa khususnya daerah kabupaten Bima, mengingat deklinasi moral (korupsi semakin membudaya, tawuran antar pelajar semakin terjadi, aborsi semakin subur, dan sederet kejahatan lainnya) yang terjadi di kabupaten Bima sangat memprihatinkan. 
Peneliti menyakini bahwa lembaga pendidikan merupakan salah satu peletak dasar pendidikan karakter. Memasukan nilai-nilai kearifan lokal (local wisdom) dalam hal ini konsep maja labo dahu dan cerita rakyat pada bahan ajar merupakan langkah antisipatif untuk meminimalisir deklinasi moral yang terjadi di Bima saat ini. Sejalan dengan itu, Mawadah, (2013), mengatakan bahwa cerita rakyat dapat dijadikan sebagai salah satu media pendidikan dalam upaya pembentukan karakter siswa, diantaranya adalah parakter yang menjunjung tinggi nilai-nilai kearifan lokal (local wisdom).

Berdasarkan uraian di atas, maka peneliti merumuskan rumusan masalah sebagai berikut, (a) Apakah Pembelajaran Sastra berbasis kearifan lokal dapat menanamkan nilai-nilai karakter pada siswa?, dan (b) Bagaimanakah desain pembelajaran sastra berbasis kearifan lokal (Cerita rakyat dan konsep maja labo dahu) sebagai upaya penanaman nilai-nilai pendidikan karakter?

\section{TINJAUAN PUSTAKA}

\section{a. Pembelajaran Sastra di SMP}

Sastra berasal dari bahasa sanskerta, dari akar kata cas yang berarti memberi petunjuk, mengarahkan, dan mengajar. Jika kita mengacu pada pengertian dari itu, maka sastra dapat dijadikan alat untuk mengajar, mengarahkan, dan petunjuk. Sedangkan menurut Diha, (2016 : 13) bahwa sastra merupakan seni menyusun kata-kata yang indah. Lain halnya, Rene dan Werren, (1977 : 15) mengatakan bahwa "one is creative, an art." Merujuk dari beberapa pendapat tersebut, dapat disimpulkan bahwa sastra merupakan suatu kajian kreatif yang penuh imajinatif serta seni menyusun kata-kata. Menurut Oemarjati dalam Tindaon bahwa pengajaran sastra pada dasarnya mengemban misi efektif, yaitu memperkaya pengalaman siswa dan menjadikannya lebih tanggap terhadap peristiwaperistiwa di sekelilingnya. Tujuan akhirnya adalah menanam, menumbuhkan, dan mengembangkan kepekaan terhadap masalah-masalah manusiawi, pengenalan dan rasa hormatnya terhadap tata nilai, baik dalam konteks individual, maupun sosial."
Hidayat, 2009 : 1), mengatakan bahwa pengajaran sastra mencakup tiga hal pokok penting, yakni kemampuan belajar, yaitu pada kemampuan afektif, kemampuan kognitif, dan kemampuan psikomotorik. Kemampuan afektif adalah kemampuan dasar manusia yang berkaitan dengan emosional seseorang. Kemampuan kognitif adalah kemampuan yang dimiliki oleh manusia berdasarkan pikiran. Sedangkan kemampuan psikomotorik adalah kemampuan mengatur sisi kejiwaan untuk bertahan terhadap berbagai persoalan. Ketiga kemampuan tersebut secara serempak dapat ditemukan dalam pengajaran sastra. Atas dasar itu, pembelajaran sastra berbasis kearifan lokal (Cerita Rakyat dan Konsep Maja Labo Dahu) sebagai upaya penanaman pendidikan karakter merupakan salah satu solusi yang dapat bisa ditawarkan untuk mengatasi deklinasi moral yang melanda siswa-siswi sekarang ini. Sebab, dalam karya sastra terkandung eksplorasi mengenai kebenaran kemanusiaan, adat istiadat, agama, kebudayaan, dan sebagainya, sastra juga menawarkan berbagai bentuk kisah yang merangsang pembaca untuk berbuat sesuatu, Tindaon, (2013: 1)

Menurut, Tindaon, (2013 : 2) bahwa pembelajaran sastra harus diarahkan pada dua tuntutan, yakni Pertama, pembelajaran sastra hendaknya mampu membina perasaan yang lebih tajam, dan kedua, bahwa pembelajaran sastra hendaknya dapat memberikan bantuan dalam usaha mengembagkan berbagai kualitas kepribadian siswa yang antara lain meliputi ketekunan, kepandaian, pengimajian, dan penciptaan. Merujuk dari pendapat tersebut bahwa pengajar harus mengarahkan pada siswa untuk mengali nilai-nilai yang terkandung dalam karya sastra tersebut karena ada banyak nilai-nilai melalui tokoh rekaan yang ada didalam karya sastra tersebut untuk dijadikan tauladan bagi siswa - siswi tersebut.

\section{b. Tujuan Pembelajaran Sastra}

Depdiknas telah merumuskan tujuan pembelajaran sastra. Dalam rumusan tersebut, ada beberapa tujuan pembelajaran sastra, yakni agar siswa mampu memahami, menikmati, dan memanfaatkan karya sastra guna mengembangkan kepribadian, memperluas wawasan kehidupan, meningkatkan 
pengetahuan, dan kemampuan berbahasa (Depdiknas, 2001). Sedangkan menurut Lazar dalam Tindao, (2014: 3), mengatakan bahwa manfaat pembelajaran sastra antara lain: (1) memberikan motivasi kepada siswa; (2) memberi akses pada latar belakang budaya; (3) memberi akses pada pemerolehan bahasa; (4) memperluas perhatian siswa terhadap bahasa; (5) mengembangkan kemampuan interpretatif siswa; dan (6) mendidik siswa secara keseluruhan.

\section{c. Konsep Kearifan Lokal}

i) Cerita Rakyat

Cerita rakyat merpakan kekayaan yang tak ternilai yang telah diwariskan para pendahulu, karena di dalam cerita rakyat sesungguhnya mengandung tatanan nilai dan pembelajaran moral budi pekerti kepada masyarakat, Alan dalam Diha, (2017:3).

ii) Ungkapan Maja Labo Dahu

Bima Nusa Tenggara Barat merupakan bagian yang tak terpisahkan dari Nusantara. Tentunya Bima memimiliki kebudayaan yang kaya akan nilai. Kebudayaan yang diwariskan oleh nenek moyang. Salah satu kebudayaan Bima yang kaya akan nilai adalah "Maja Labo Dahu." Maja Labo Dahu yang memiliki makna kurang lebih malu dan takut kepada Allah jika melakukan perbuatan yang keluar dari ajaran yang mereka anut, yakni Islam. Konsep maja labo dahu merupakan falsafah orang Bima yang selalu dipegang teguh dimanapun mereka melangkahkan kakinya.

Ungkapan tersebut sangat cocok bagi masyarakat Bima yang kental dengan semangat ke-Islamannya. Masyarakat Bima sebetulnya sangat menjunjung tinggi nilai-nilai ke Islaman. Menurut, Didi Haryono, dalam Mbojoklopedia mengatakan bahwa penerapan nilai-nilai islam dalam kehidupan masyarakat Bima (dou Mbojo) begitu melekat dalam keseharian mereka, penerapan hukum sara' (syariat) oleh kesultanan menjadi aturan yang mengikat seluruh kehidupan dou Mbojo. Salah satu contoh dari kegethuan masyarakat Bima memengang teguh nilai - nilai ke-Islaman itu adalah bahwa para wanita yang sudah akil balik jika keluar rumah, maka mereka selalu menutup auratnya dengan menggunakan rimpu. Maja labo dahu berkaitan dengan moralitas publik seorang individu ketika memangkujabatan dalam pemerintahan, dan sedikit banyak turut mempengaruhi sistem, pada awalnya, nilai Maja labo dahu berfungsi dalam bidang pemerintahan sebagai wadah suatu kekuasaan yang menggerakkannya, daripada sebagai subjek atau penanggungjawab tindakan-tindakannya, Nurhayati, (2006: 1).

Menurut Nurhayati, (2006 :6) bahwa ada emapt aspek yang ada di dalam maja labo dahu, yakni pertama Pertama, manusia melakukan interaksi dengan dirinya. Kedua, wujud kehidupan manusia dengan manusia lainnya, Ketiga, wujud kehidupan manusia dengan lingkungannya, dan keempat, wujud kehidupan manusia dengan Tuhannya. Dalam diri manusia Bima yang maja labo dahu sesungguhnya tertanam nilai kejujuran, kesederhanaan, kerja keras dan keuletan.

Menurut, Maryati, (2013 : 3) bahwa Maja Labo Dahu bagi masyarakat Bima pada masa lalu, merupakan warisan budaya yang amat berharga untuk dijadikan pedoman dalam kehidupan, guna mewujudkan kebahagiaan dunia dan akhirat. Pada masa kesultanan, Maja Labo Dahu menjadi sumber kekuatan bathin,bagi pemerintah dan rakyat dalam mengemban tugas. Mungkin itulah salah satu yang membuat kesultanan Bima mengalami kejayaan pada waktu yang lama.

Merujuk dari pendapat tersebut di atas bahwa konsep maja labo dahu memiliki hubungan erat dengan nili - nilai ke - Islaman masyarakat Bima, sebab dalam Islam, proses interaksi dengan diri, hubungan dengan manusia yang satu dengan manusia yang lain, mengenal dan memilihara lingkungan, dan hubungan manusia dengan Tuhan merupakan bagian dari ajaran Islam. Nilai-nilai tersebut include ada di dalam konsep maja labo dahu. Berangkat dari itu, konsep maja labo dahu menjadi salah satu alat untuk dijadikan bahan ajar di sekolahsekolah guna menanamkan nilai-nilai pendidikan karakter di siswa-siswa, karena konsep maja labo dahu dan nilai-nilai pendidikan karakter miliki kesamaan, sebab konsep maja labo dahu merupakan salah satu 
ungkapan yang dimiliki oleh masyarakat Bima yang memiliki makna ajakan kepada kebaikankebaikan, yakni malu dan takut jika melakukan korupsi, tidak sopan, dan sejenisnya.

\section{METODE PENELITIAN}

Penelitian ini menggunakan jenis penelitian pengembangan. Menggunakan jenis penelitian pengembangan karena dalam penelitian ini akan mengghasilkan produk pengembangan, yakni design pembelajaran sastra (cerita rakyat dan konsep maja labo dahu). Langkah yang ditempuh oleh peneliti adalah (1) penelitian dan pengumpulan informasi awal; (2) perencanaan; (3) pengembangan produk awal; (4) evaluasi awal; ( 5) revisi produk; (6) implementasi; (7) evaluasi akhir. Dalam penelitian pengembangan ini, peneliti berupaya mengembangkan bahan ajar pengajaran sastra berbasis kearifan lokal, yakni cerita karyat dan konsep maja labo dahu sebagai langkah antisipatif deklinasi moral pada generasi penerus bangsa. Penelitian ini dilakukan di tiga sekolah, yakni SMP N 7 Monta, MTs Sila, dan SMP PGRI Belo. Tehnik pengumpulan data melalui : observasi, Teknik wawancara (interview), Tehnik rekaman, Tehnik dokumentasi. Sedangkan Tekhnik Analisis data menikuti langkah sebagai berikut; 1) membaca data yang telah dikumpulkan, 2) mengklarifikasi data yang dibutuhkan, 3) menganalisis dan menginterpretasi data, dan 4) membuat kesimpulan. Untuk mengabsahkan data, peneliti menggunakan triangulasi data, yakni peneliti membandingkan dengan berbagai teori yang yang berkaitan dengan subjek penelitian, selanjutnya peneliti akan berdiskusi dengan teman sejawat untuk menentukan tindakan selanjutnya.

\section{HASIL DAN PEMBAHASAN}

Penelitian ini dilakukan guna memperoleh gambaran tentang desain pembelajaran sastra berbasis kearifan lokal, dalam hal ini cerita rakyat dan konsep falsah orang Bima terkait maja labo dahu. Cerita rakyat dan konsep maja labo dahu merupakan salah satu jawaban atas krisis moral generasi pelangsung bangsa ini. Sebab, cerita rakyat dan maja labo dahu mengandung nilai - nilai pendidikan karakter. Hal itu sangat cocok dijadikan alat untuk menanamkan nilai pendidikan karakter pada siswa tersebut. Maja labo dahu memiliki makna yang sangat luas yang mengangkut segala lini kehidupan. Sebab, konsep maja labo dahu memiliki makna kurang lebih malu dan taku jika melakukan sesuatu yang menyimpang dalam norma yang berlaku. Dalam konteks ini, peneliti menguraikan tentang (a) pembelajaran sastra berbasis kearifan lokal (cerita rakyat dan konsep maja labo dahu) dapat menanamkan nilai nilai karakter siswa, dan (b) desain pembelajaran sastra berbasis kearifan lokal (cerita rakya dan konsep maja labo dahu) sebagai upaya penanaman nilai pendidikan karakter siswa.

a. Pembelajaran sastra berbasis kearifan lokal dapat menanamkan nilai - nilai pendidikan karakter sisiwa.

Tidak bisa dinafikan bahwa di era digitalisasi ini, generasi muda mengalami krisis diberbagai lini, salah satunya adalah terkait moral peserta didik. Peserta didik merupakan generasi pelangsung bangsa yang mesti harus dijaga. Sebab, nasib bangsa 20 tahun kedepan akan ditentukan oleh generasi atau peserta didik hari ini. Dalam kalimat lain bahwa jika moral generasi pelangsung bangsa hari ini rusak, maka sudah bisa dipastikan bahwa bangsa kedepan juga akan rusak. Untuk itu, perlu dilakukan tawaran-tawaran solusi untuk memparaiki Sumber Daya Manusia (SDM) kedepannya. Salah satu solusi yang dilakukan adalah pembelajaran berbasis kearifan lokal (cerita rakyat dan konsep maja labo dahu). Pembelajaran, khususnya pembelajaran bahasa dan sastra mesti dilakukan dengan pendekatan - pendekatan berbasis kearifan lokal. Nilai - nilai kearifan lokal (nilai - nilai yang terkandung dalam cerita rakyat dan maja labo dahu) harus dijadikan salah satu materi atau bahan ajar. Sebab dalam cerita rakyat dan konsep maja labo dahu memiliki kesamaan makna dengan pendidikan karakter. Dalam kalimat lain bahwa nilai-nilai pendidikan karakter bisa digali melalui cerita rakya dan falsafah maja labo dahu tersebut.

Penelitian ini dilakukan di beberapa sekolah yang ada di kabupaten Bima dan dilakukan wawancara beberapa guru dan 
siswa terkait konsep kearifan lokal, dalam hal ini menggali nilai - nilai pendidikan karakter melalui cerita rakyat dan falsafah maja labo dahu. Cerita rakyat dan falsafah maja labo dahu memiliki hubungan erat dengan penanaman nilai pendidikan kakrakter. Hal itu dapat dilihat dari hasil wawancara yang dilakukan oleh peneliti dengan salah satu guru yang mengajar bahasa Inggris. Peneliti berhasil mewawancarai guru tersebut.

"Dalam cerita rakyat lokal terdapat banyak nilai pendidikan karakter yang bisa digali. Nilai - nilai tersebut dapat dijadikan contoh oleh guru. Nilai - nilai tersebut adalah kejujuran, disiplin, relegius, amanah, dan lain sebagainya. Nilai - nilai itu dapat ditiru oleh siswa. Dalam artian bahwa guru harus menceritakan kepada siswa tentang nilai - nilai kebaikan yang ada di dalam tokoh tokoh rekaan di cerita rakyat tersebut." Hasil wawancara dengan guru, Muliati"

Berdasarkan pernyataan tersebut di atas bahwa nilai - nilai pendidikan karakter dapat digali melalui cerita rakyat, dalam hal ini cerita rakyat yang ada di daerah tersebut. Sebab, cerita rakyat dapat mengaktifkan imajinasi siswa dalam merenung hal - hal kebaikan. Sejalan dengan itu, Tuhusetya dalam Juwita, (2018 : 682) mengatakan bahwa pembelajaran sastra selain dapat menggiring anak untuk gemar membaca dan menulis, sastra juga dapat menjadi wahana penanaman nilai-nilai kehidupan bagi manusia yang berbudaya. Dengan membaca teks sastra, nurani pembaca menjadi lebih peka terhadap persoalan hidup dan kehidupan. Sebab, sastra diciptakan dengan mempertimbangkan kode bahasa, kode budaya, dan kode sastra.

Pernyataan tersebut juga didukung oleh salah satu guru bahasa Inggris di MTs Sila, Susilawati. Susilawati mengatakan bahwa teks cerita rakyat yang lahir dari masyarakat setempat sangat cocok untuk dijadikan bahan ajar dalam salah satu materi, sebab siswa sudah sangat femiliar dengan cerita tersebut. Tingal bagaimana seorang guru mengajarkan dan menggali nilai - nilai tersebut.

"Salah satu bahan ajar, khususnya mata pelajaran bahasa dan sastra, mestinya memperhatikan nilai - nilai lokal. Salah satu cara memperhatikan nilai - nilai lokal itu adalah menceritakan cerita rakyat kepada siswa, dan dalam cerita rakyat tersebut terdapat nilai - nilai kebaikan yang dapat dijadikan contoh kepada siswa. Hal itu juga sejalan dengan nilai pendidikan karakter," hasil wawancara dengan Susisulawati

Falsah maja labo dahu dan pendidikan karakter terdapat kesamaan. Dalam kalimat lain bahwa nilai - nilai pendidikan karakter secara explisit juga terdapat pada falsafah maja labo dahu tersebut. Dalam pendidikan karakter terdapat delapan belas nilai nilai pendidikan karakter, yakni (1) Nilai Relegius, (2) Jujur, (3) Toleran, (4) Disiplin, (5) Kerja Keras, (6) Kreatif, (7) Mandiri, (8) Demoktratis, (9) Rasa Ingin tahu, (10) Semangat kebangsaan, (11) Cinta tanah air, (12) Menghargai Prestasi,

Bersahabat/komunikatif, (14) Cinta damai, (15) Gemar Membaca, (16) Peduli Lingkungan, (17) Peduli Sosial, dan (18) tanggung jawab. Begitu juga makna falsafah maja labo dahu. Falsafah maja labo dahu memiliki makna malu dan taku jika melakukan hal - hal yang melanggar norma yang berlaku pada masyarakat. Nilai - nilai tersebut dapat digali pada cerita rakyat yang ada di kabupaten Bima.

b. Desain pembelajaran siswa berbasis kearifan lokal (cerita rakya dan konsep maja labo dahu) sebagai upaya penanaman nilai pendidikan karakter siswa.

Cerita rakyat merupakan salah satu genre yang berupa tradisi lisan yang diceritakan secara turun temurun oleh para pendahulu. Dalam kalimat lain bahwa penyebaran cerita rakya melalui tradisi lisan. Cerita rakyat dapat diartikan sebagai cerita lisan yang meliputi legenda, music, sejarah lisan, pepatah, lelucon, takhayul, dongeng, kebiasaan menjadi tradisi dalam suatu budaya, subkultur, atau kelompok. Dalam bahasa sehari-hari cerita rakyat lebih dikenal 
masyarakat sebagai dongeng, Sumayana, (2017 : 22). Cerita rakyat juga dianggap sebaggai dongeng yang dianggap fiktif belaka, sebab cerita rakyat tidak diketahui pemilik atau pengarangnya. Namun, dibalik itu semua, cerita rakyat memiliki makna yang sangat luas. Salah satunya adalah nilai pendidikan karakter. Melalui tokoh rekaan yang terdapat di dalam cerita rakyat tersebut, seorang guru dan siswa dapat meniru prilaku baik tokoh rekaan tersebut.

Dalam penelitian ini, penulis mencoba menawarkan solusi menggingat krisis moral yang tidak berkesudahan di negeri ini. Salah satu solusinya adalah mendesain bahan ajar berbasis kearifan lokal, dalam hal ini cerita rakyat dan falsafah maja labo dahu. Pembelajaran berbasis kearifan lokal adalah salah satu pembelajaran alternatif ditengah krisi moral generasi penerus bangsa ini. Pengembangan bahan ajar berbasis kearifan lokal ini dapat menjadi sebuah alternatif pemerkayaan pembelajaran bagi guru. Dalam kalimat lain bahwa seorang guru dapat menggali nilai nilai pendidikan karakter melalui cerita rakyat yang ada di wilayah setempat dan menggali nilai nilai filsafat lokal. Sebab, cerita rakyat yang ada di wilayah setempat dan filsafal atau ungkapan lokal memiliki kesamaan dengan karakter sisiwa. Hal itu didukung oleh Salmah salah seorang guru di SMP PGRI Belo. Salmah mengatakan bahwa tokoh tokoh rekaan yang ada di dalam cerita rakyat setempat memiliki karakter yang sama dengan orang yang setempat. Selain itu juga, ungkapan-ungkapan lokal memiliki nilai yang hampir mirp dengan pendidikan karakter.

"Tokoh rekaan yang terdapat di dalam cerita rakyat yang lahir di wilayah setempat memiliki kesamaan dengan karakter orang yang tinggal di wilayah setempat. Nilai nilai kebaikan tersebut tentu akan memiliki nilai kebaikan juga. Hal itu bisa dijadikan salah satu contoh yang harus diajarkan kepada siswa tersebut. Begitu pula dengan ungkapan ungkapan yang dijadikan motto suatu daerah, salah satu contoh misalnya di daerah Mbojo sangat populer dengan ungkapan maja labo dahu. Maja labo dahu memiliiki makna yang sangat luas. Jika di artikan secara literal, maka maknanya malu dan taku jika melakukan hal buruk di tengah masyarakat," Hasil wawancara dengan Salmah.

\begin{tabular}{|l|l|l|}
\hline No & \multicolumn{1}{|c|}{$\begin{array}{c}\text { Nilai nilai } \\
\text { ungkapan maja } \\
\text { labo dahu }\end{array}$} & $\begin{array}{c}\text { Nilai pendidikan } \\
\text { karakter }\end{array}$ \\
\hline 1. & Jujur & Religius \\
\hline 2. & Komitmen & Jujur \\
\hline 3. & Kerja keras & Kerja keras \\
\hline 4. & Tepat janji & Ingin tahu \\
\hline 5. & Tanggung jawab & Cinta tanah air \\
\hline 6. & Disiplin & $\begin{array}{l}\text { Semangat } \\
\text { kebangsaan }\end{array}$ \\
\hline
\end{tabular}

Berdasarkan pernyataan tersebut di atas bahwa desain pembelajaran sastra berbasis kearifan lokal merupakan salah satu pembelajaran alternatif yang bisa dilakukan guna meminimalisir krisis moral generasi penerus bangsa ini. Untuk itu, langkah yang harus dilakukan untuk mendesain pembelajaran berbasis kearifan lokal di sekolah khususnya di Sekolah Menengah Pertama (SMP) sederajat adalah;

a. Menidentifikasi nilai - nilai kearifan lokal (nilai nilai yang terkadung dalam cerita rakyat dan filsafah maja labo dahu) untuk dijadikan bahan ajar atau salah satu materi; dan

b. Memasukan nilai - nilai kearifan lokal (nilai nilai yang terkadung dalam cerita rakyat dan filsafah maja labo dahu) kedalam materi atau bahan ajar.

Nilai nilai kearifan lokal (nilai nilai yang terkadung dalam cerita rakyat dan filsafah maja labo dahu) dapat mempengaruhi sikap dan tingkah laku seseorang dalam kesehariannya. Hal itu secara tidak langsung cerita rakyat dan filsafah maja labo dahu dapat mempengaruhi sikap dan prilaku peserta didik. Sejalan dengan itu, Prasetyo, dkk dalam Juwati, (2018 : 688) mengatakan bahwa cerita rakyat berfungsi (1) dapat menciptakan emosi kasih sayang yang mengarah pada kebaikan, hasrat untuk melakukan perbuatan yang benar; (menyediakan kekayaan keteladanan akan kebaikan; (3) dapat membiasakan remaja 
dengan aturan moral yang perlu mereka ketahui; dan (4) dapat membantu untuk membuat pengertian kehidupan, membantu untuk menciptakan kehidupan diri sendiri sebagaimana sebuah cerita yang ada dalam cerita rakyat.

Hal itu juga terdapat dalam nilai nilai maja labo dahu

\section{KESIMPULAN}

Berdasarkan penjelasan tersebut di atas, maka dapat ditarik simpulan bahwa desain pembelajaran sastra berbasis kearifan lokal (cerita rakyat dan konsep maja labo dahu) sebagai upaya penanaman pendidikan karakter perlu dilakukan. Karena dalam ungkapan maja labo dahu dan pendidikan karakter memiliki kesamaan. Desain pembelajaran berbasis kearifan lokal merupakan salah satu metode yang harus dipilih oleh guru dalam mendesain bahan ajar guna menanamkan nilai - nilai pendidikan karakter pada peserta didik, khususnya pada peserta didik di tingkat Sekolah Menengah Pertama (SMP).

\section{Saran}

Berdasarkan hasil temuan dalam penelitian ini, maka peneliti merekomendasikan atau menyarankan bahwa perlu dilakukan desain pembejalaran sastra berbasis kearifan lokal, dalam hal ini memanfaatkan bahan lokal dalam mendesain bahan pembelajaran. Dalam kalimat lain bahwa guru -guru dalam hal ini, perlu memanfaatkan karya sastra lokal sebagai salah satu bahan pembelajan di tingkat SMP sederajat. Selain itu, jam mata pelajaran Bahasa dan Sastra perlu ditamba guna memaksimalkan penanaman pendidikan karakter pada siswa.

\section{DAFTAR PUSTAKA}

\section{Buku}

Cressweel, John W. 2012. Research design pendekatan kualitatif, kuantitaf, dan mixed. Pustaka Pelajar. Yogyakarta

Diha, Hamjah. 2017. Sang Predator. Mataram. Lembaga Penerbit Yayasan Hamjah Diha

2017. Teori Sastra. Sebuah Pengantar Awal. Mataram. Lembaga Penerbit Yayasan Hamjah Diha.
Endraswara, Suwardi. 2013. Metodologi Penelitian Sastra. Epistemologi, Model, Teori, dan Aplikasi. Yogyakarta. Penerbit Pustaka Widayatama.

Martono, Nanang. 2015. Metode Penelitian Sosial. Kosep-konsep kunci. Jakarta. Rajawali Press.

Wagiran. 2012. Pengembangan karakter berbasis kearifan lokal Hamemayu hayuning bawana (Identifikasi Nilainilai Karakter Berbasis Budaya). Jurnal Pendidikan Karakter, Tahun II, Nomor 3 tahun 2012.

UU RI 20 tahun 2003 tentang Sistem Pendidikan Nasional

\section{Makalah}

Tindao, Yosi Abdian. 2017. Pembelajaran Sastra Sebagai Salah Satu Wujud Implementasi Pendidikan Berkarakter.

Sumayana, Yena. 2017. Pembelajaran Sastra Di Sekolah Dasar Berbasis Kearifan Lokal (Cerita Rakyat). Mimbar Sekolah Dasar, Vol 4(1) 2017, 21-28

Istiqomah, Wanti Nur dan Aan Kusdiana. 2018. Pengembangan Bahan Ajar Pembelajaran Berbicara Berbasis Kearifan Lokal Melalui Permainan Bahasa di Sekolah Dasar. PEDADIDAKTIKA: JURNAL ILMIAH PENDIDIKAN GURU SEKOLAH DASAR - Vol. 5, No. 4 